\title{
An Evaluation of Local and Oral History of Cyprus Teaching on the Basis of Postmodern Education: Student and Teacher Opinions
}

\author{
Ayten Koruroğlu ${ }^{1 *}$, Ali Efdal Özkul ${ }^{1}$ \\ ${ }^{1}$ Near East University, Ataturk Faculty of Education, Nicosia, NORTHERN CYPRUS
}

Received 22 June 2017 • Revised 8 September 2017 • Accepted 8 October 2017

\begin{abstract}
In postmodern education philosophy, the areas of interest of students, studentoriented teaching and regulating learning-teaching environments according to the student are essential. Based on this viewpoint, the purpose of this research is to evaluate the student-related factors in terms of Cyprus history. The aim is to determine the attitudes of students towards Cyprus history (in the case of local-oral history) and to explore the student-related problems from the perspective of teachers in particular. In the study, the attitude levels of students are determined and the problems experienced in Cyprus history are described; furthermore, this is followed by a discussion on postmodern education and local-oral history education. Postmodern education in the case of Cyprus history is evaluated. In this context, the problem sentence of the research is as follows: "What are the student and teacher opinions in regard to local and oral Cyprus history education on the basis of postmodern education?" The model of this study is a mixed research method, which is based on both quantitative and qualitative data. Stratified random sampling was used in this study and a total of 800 secondary and high school students from five different districts of Cyprus were reached.
\end{abstract}

Keywords: postmodernism, postmodern education, local history, oral history, Cyprus history

\section{INTRODUCTION}

This is an era of information when an innovative understanding is adopted in every aspect of life. New approaches and new directions in education and educational programs are also products of the progress experienced in the modern era. Within the framework of this modernization and progress, it is necessary to add a new dimension to education programmes and to follow new trends. In this context, the postmodern approach assumes prominences, postmodernism is a contemporary approach with a wholly liberal character.

As having an attitude against modernism, postmodernism appears as a higher dimension of modernism and questions, criticizes, debates and re-discusses the fundamental assumptions of modernism (Lyotard, 2000; Hollinger, 2005; Sarup, 2004; Doltaş, 2003).

Postmodernists see the world as a changeable and diverse pattern. As it is movable and changing, they prefer to use verbs instead of subjects (Aydın, 2006; Nicholls, 2006; Carda, 2013; Lixin, 2004; McCrum, 2010; Hughson, 2013).

In a postmodern education program, students are allowed the freedom to move inside and outside the programme. Students are free to explore alternatives, ask questions and make their own interpretations. In such a program, the educational targets are not determined in advance as they are inside the learning process. Learning is constructed by the teacher and the student in collaboration. According to postmodernist philosophy, history is a discourse created by interpreting the past, which is particularly influenced by language. Postmodernists argue that history is not objective but subjective (Iggers, 2000; Jenkins, 1997; Y1lmaz, 2013).

Postmodernism criticizes the behavouralist approach and the application the of classroom methods based on this approach. It is widely acknowledged that history classes are perceived as being based on the memorizing of 


\section{Contribution of this paper to the literature}

- Give a good model for student centered history education and discuss postmodern history education.

- Understand the attitudes of students in history education and organize teaching-learning activities.

- Solve problems in Cyprus history education for both teachers and also students.

the names of persons, places and dates by students. For this reason, while planning history teaching, the teachercentred and course-book oriented teaching approach must be abandoned. Instead, dialogue-based learning through Socratic dialogue and exploration, and problem-based learning approaches must be applied in classrooms in order to ensure that students develop their own knowledge and perception of history (Jenkins, 1997; Boboc, 2012; Coleman, 2002).

History must be taught in a manner through which students can gain a different perspective and interpretation of history. History teaching must not be based on memorizing but on changing the students' perception of the past and the manner in which they approach historical events, as well as improving their understanding; in short, by creating a personal transformation process in history learning (Y1lmaz, 2013 ; Boboc, 2012; Coleman, 2002; Hart, 2007).

On the contrary to traditional history, postmodern history understanding it does not think that history writing should be only based on written sources and archival documents. As it assigns importance to popular culture, postmodernism argues that local and oral history methods should be utilized in history writing. The people and groups that are not included in history books must be researched, the events deemed to be important by the local community must be examined, and daily life must be discussed. Postmodernism values locality and local culture. In this context, postmodernism sees oral history as the most suitable approach for examining local history (Caunce, 2001; Tosh, 2005; Thomson, 1999; Özer, 2012).

In postmodern education understanding, the interest status of students, student-oriented teaching and organizing learning-teaching according to students is essential. Based on this viewpoint, the purpose of this research is to evaluate the element of student in Cyprus history. The aim is to determine the attitude level of students towards Cyprus history (in the case of local-oral history) and to especially explore the student-related problems from the eyes of teachers. In the study, attitude levels of students are determined and the problems experienced in Cyprus history are described, and a discussion is planned on postmodern education and local-oral history education. Thus, the existing situation is displayed (especially on the basis of student attitudes and behaviours) and its place vis-à-vis postmodern education in the case of Cyprus history is evaluated. In this context, the problem sentence of the research is as follows: "What are the student and teacher opinions in regard to local and oral Cyprus history education on the basis of postmodern education?" Sub-problems are identified as follows:

1. What are the attitude levels of students towards Cyprus history and which variables influence these attitudes?

2. What are the problems students experience in terms of Cyprus history according to teachers?

\section{METHOD}

Based on the problem of the research, information will be given on the research problem, its participants, as well as the collection and analysis of data.

\section{Research Model}

An evaluation on local and oral Cyprus history education on the basis of postmodern education: the model of this research aimed at testing the opinions of students and teachers is a mixed research model, which is based on both quantitative and qualitative data. In recent years, particularly in education and social field studies, the "mixed method approach" has been gaining popularity due to the fact that it enables researchers to collect multiple data using different approaches, methods and techniques and that these data complete and support each other (Johnson \& Turner, 2003).

\section{Sample}

Stratified random sampling was used in the study to reach 800 secondary and high school students in five different districts of Cyprus. The distribution of the personal characteristics of the students shows that 50.0 percent of students were females and 50.0 percent were males. Furthermore, $8.50 \%$ of students were below 12 years of age, whereas $17.13 \%$ were $13,16.63 \%$ were $14,24.25 \%$ were $15,21.50 \%$ is were 16 and $12.0 \%$ were 17 or over. 
An examination of the students according to their education status shows that $43.63 \%$ of the covered students were attending secondary school and $56.37 \%$ were at the high school level. Additionally, $88.0 \%$ of the participant students were at public schools, whereas $12.0 \%$ were at private schools. A total of $15.37 \%$ of the students had received a report grade of 4 or below in the previous year, whereas $28.0 \%$ had scores of 5 and $6,29.63 \%$ had scores of 7 and 8 , and $27.0 \%$ had scores of 9 and 10 .

Daily Internet usage, hours spent watching TV and the time students spent reading newspapers were also questioned. The findings reveal that $24.50 \%$ of students used the Internet for 1 hour or less, $23.0 \%$ used the Internet for $1-2$ hours, $14.88 \%$ used it for $2-3$ hours and $37.63 \%$ used the Internet for 3 hours or more. The daily TV watching figures of students show that $41.0 \%$ watched TV for 1 hour or less, $26.13 \%$ watched TV for $1-2$ hours and $32.88 \%$ watched TV for more than 2 hours. Finally, 37.38\% of students declared that they read newspapers, $25.0 \%$ stated that they sometimes read newspapers and $37.63 \%$ stated that they did not read newspapers.

Additionally, 22 history teachers delivering Cyprus history classes in these schools were chosen based on purposive sampling.

\section{Data Collection Tools}

\section{Quantitative data collection tools}

Questionnaires completed by the students in the sample were used in collecting the research data. The questionnaire used as data collection tool consists of two sections, namely Personal Information and the Cyprus History Attitude Scale.

\section{Personal information}

In the personal information section prepared by the researcher, which is in the first part of the questionnaire, questions for identifying the introductory information of students, such as gender and age, data on their school achievements and the class they are in, newspaper reading habits, television watching and Internet usage data, as well as their level of information on Cyprus history based on their own quotations, are included.

\section{Cyprus History Attitude Scale}

In order to identify the attitude of students on Cyprus History, the Cyprus History Attitude Scale developed by Mustafa Safran's (1993), as adapted to the students studying, in Cyprus was used.

The scale consists of 10 negative and 10 positive propositions prepared in a 5-point Likert format. The answers given to the positive propositions in the scale given by students were scored as "totally disagree - 1 point", "disagree - 2 points", "neutral - 3 points", "agree - 4 points", and "totally agree - 5 points". Negative propositions in the scale are reversely scored from 5 to 1 . The lowest and highest scores that can be obtained from the scale are 20 and 100 , respectively. Factor analysis was utilised in this case in order to ensure the structural validity of the scale. Exploratory factor analysis can be used in order to identify the factor structure of the scale, and confirmatory factor analysis can be used in order to verify the structure of the pre-set factors (Büyüköztürk et al., 2008). Confirmatory Factor Analysis (CFA) was used to ensure the structural validity of the Cyprus history attitude scale. CFA is used in identifying whether the findings obtained from the answers of the participants correspond with the theoretical structure (Çapık, 2014).

\section{Qualitative data collection tools of the study}

In the data collection process, the opinions of history teachers were consulted through a semi-structured interview form, which was prepared in advance after consulting expert opinion in regard to the collection of qualitative data of the study while applying the attitude scale in all schools in the TRNC. Semi-structured interview forms enable respondents to answer based on fixed options and allows the researcher to obtaining detail data in the relevant area (Yıldırım \& Şimşek, 2013).

In this context, semi-structured interview forms were prepared based on expert views in order to gather the teachers' opinions. The interview form, which was prepared as the Teacher Opinions on Problems and Solutions in Cyprus History Classes, consists of two sections, namely problems and solutions. In the problems section, seven questions were asked, whereas in the solutions section, four questions were asked to collect the teacher opinions. Interviews were conducted with a total of 21 teachers. 


\section{Collection of Data}

For the purposes of the needs analysis in the research, permission was obtained from the TRNC Ministry of Education for the attitude scale, which was designed to be applied in schools reporting to the ministry. After obtaining the necessary permission from the ministry on 20.04.2016, the researcher visited all secondary schools throughout the TRNC between 25.04.2016 and 30.05.2016 in order to collect the relevant data.

\section{Analysis of Data}

\section{Analysis of quantitative data}

When evaluating the research data, SPSS 21 and AMOS 21, which are software packages for statistical data analysis, were used.

Frequency analysis was used in determining the social-demographic characteristics of the students covered in the research and the results are shown in frequency tables. Distribution of the answers given by the students to the Cyprus History Attitude Scale was identified with frequency distribution and average scores for each proposition were provided.

Kolmogorov-Smirnov, Shapiro-Wilk test, Q-Q plot and skewness-kurtosis values were examined to determine the conformity of the dataset to normal distribution in order to identify the hypothesis tests which would be used in comparing the scale scores, based on certain characteristics of the students covered in the study. As a result of the conducted evaluation, it was identified that the scale scores of students confirmed to normal distribution for some of the characteristics, while they did not conform for others. Accordingly, both parametric and nonparametric hypothesis tests were used in the study.

Parametric hypothesis tests were used in comparing the Cyprus History Attitude Scale scores of the students based on their introductory characteristics, school characteristics, Internet usage, TV watching period and newspaper reading habits. In comparisons where the independent variable consists of two categories, the independent sampling $\mathrm{t}$ test was conducted, whereas when the independent variable consisted of more than two categories, variance analysis was employed. If differences were observed between the categories of the independent variable as a result of variance analysis, Tukey's test was conducted to determine the category in which the difference occurred.

In comparing the Cyprus History Attitude Scale scores of students in terms of their level of knowledge on Cyprus history, opinions on the course books, and their interests in reading and researching, the Kruskal-Wallis test was used as the data set did not coincide with normal distribution and the independent variables had more than two categories. The Mann-Whitney U test was used to determine the category in which the difference occurred (if there was any difference) between the categories of the independent variable.

Additionally, the dependent $\mathrm{t}$-test was used to analyse the data obtained from the achievement tests of the activity research application group students, both before and after the activity, to investigate whether the scores after the activity were different from the scores before the activity.

\section{Analysis of qualitative data}

The semi-structured interview form applied to teachers was analysed through a content analysis form in order to obtain data. Content analysis ensures that concepts, judgements and relations that explain the data can be reached. In content analysis, the aim is to subject the obtained data to in-depth examination and to reach conclusions that cannot be easily reached by performing in-depth examination (Yıldırım \& Şimşek, 2013). For this reason, the content analysis method was applied in analysing the qualitative data.

\section{FINDINGS}

In the study, quantitative findings are presented first, followed by the qualitative findings. Quantitative findings are presented in Tables 1 to 5, whereas Tables 6 and 7 provide the qualitative findings.

\section{Quantitative Findings}

When Table 1 is examined, it can be seen that students generally answered "agree" to the propositions in the scale, such as item 6, 18 and 20, whereas they answered "disagree" to such propositions as item 5, 7, 8 and 14. Some students said they agreed and others said they disagreed on other propositions in the scale; it was found out that the students were mostly neutral on such propositions. 
Table 1. Distribution of answers given by students to the Cyprus History Attitude Scale

\begin{tabular}{|c|c|c|c|c|c|c|c|c|c|c|c|}
\hline & \multicolumn{2}{|c|}{$\begin{array}{c}\text { Totally } \\
\text { disagree }\end{array}$} & \multicolumn{2}{|c|}{ Disagree } & \multicolumn{2}{|c|}{ Neutral } & \multicolumn{2}{|c|}{ Agree } & \multicolumn{2}{|c|}{$\begin{array}{l}\text { Totally } \\
\text { agree }\end{array}$} & \multirow[t]{2}{*}{$\bar{x}$} \\
\hline & $\mathbf{n}$ & $\%$ & $\mathbf{n}$ & $\%$ & $\mathbf{n}$ & $\%$ & $\mathbf{n}$ & $\%$ & $\mathbf{n}$ & $\%$ & \\
\hline \multicolumn{12}{|l|}{ Positive propositions } \\
\hline 1. History of Cyprus is an interesting subject. & 122 & 15.25 & 164 & 20.50 & 190 & 23.75 & 229 & 28.63 & 95 & 11.88 & 3.01 \\
\hline 2. History of Cyprus is a subject that I really like & 89 & 11.13 & 110 & 13.75 & 175 & 21.88 & 264 & 33.00 & 162 & 20.25 & 3.38 \\
\hline 4. History of Cyprus is easy for me. & 83 & 10.38 & 97 & 12.13 & 249 & 31.13 & 230 & 28.75 & 141 & 17.63 & 3.31 \\
\hline 6. I am trying to do my best in the History of Cyprus class. & 63 & 7.88 & 64 & 8.00 & 111 & 13.88 & 265 & 33.13 & 297 & 37.13 & 3.84 \\
\hline 9. History of Cyprus is necessary to understand world events. & 102 & 12.75 & 135 & 16.88 & 226 & 28.25 & 197 & 24.63 & 140 & 17.50 & 3.17 \\
\hline $\begin{array}{l}\text { 13. One benefit of History of Cyprus is that it is used to solve daily } \\
\text { problems. }\end{array}$ & 145 & 18.13 & 147 & 18.38 & 271 & 33.88 & 127 & 15.88 & 110 & 13.75 & 2.89 \\
\hline 15. I like studying History of Cyprus. & 106 & 13.25 & 125 & 15.63 & 193 & 24.13 & 205 & 25.63 & 171 & 21.38 & 3.26 \\
\hline $\begin{array}{l}\text { 17. When learning about the History of Cyprus, I always read a } \\
\text { publication that is suitable for my level (magazine, book, newspaper) }\end{array}$ & 171 & 21.38 & 204 & 25.50 & 195 & 24.38 & 148 & 18.50 & 82 & 10.25 & 2.71 \\
\hline $\begin{array}{l}\text { 18. I am proud of my studies in the History of Cyprus class and } \\
\text { achievements in the related tests }\end{array}$ & 84 & 10.50 & 90 & 11.25 & 225 & 28.13 & 227 & 28.38 & 174 & 21.75 & 3.40 \\
\hline 20. History of Cyprus has a special place in modern society. & 91 & 11.38 & 84 & 10.50 & 200 & 25.00 & 217 & 27.13 & 208 & 26.00 & 3.46 \\
\hline \multicolumn{12}{|l|}{ Negative propositions } \\
\hline $\begin{array}{l}\text { 3. There is no creativity in } \vdash \\
\text { memorizing names and dat }\end{array}$ & 145 & 18.13 & 202 & 25.25 & 171 & 21.38 & 165 & 20.63 & 117 & 14.63 & 2.88 \\
\hline 5. History of Cyprus is not useful as it focuses mostly on the past & 228 & 28.50 & 248 & 31.00 & 164 & 20.50 & 96 & 12.00 & 64 & 8.00 & 2.40 \\
\hline 7. I do not like History of Cyprus. & 287 & 35.88 & 227 & 28.38 & 120 & 15.00 & 82 & 10.25 & 84 & 10.50 & 2.31 \\
\hline 8. History of Cyprus has no relevanc & 233 & 29.13 & 245 & 30.63 & 178 & 22.25 & 84 & 10.50 & 60 & 7.50 & 2.37 \\
\hline 10. History of Cyprus is a boring and monotonous subject. & 226 & 28.25 & 234 & 29.25 & 170 & 21.25 & 94 & 11.75 & 76 & 9.50 & 2.45 \\
\hline 11. I do not read History of Cyprus books other than the cours & 147 & 18.38 & 167 & 20.88 & 163 & 20.38 & 182 & 22.75 & 141 & 17.63 & 3.00 \\
\hline 12. I would not study History of Cyprus if I was not forced to. & 204 & 25.50 & 167 & 20.88 & 144 & 18.00 & 148 & 18.50 & 137 & 17.13 & 2.81 \\
\hline $\begin{array}{l}\text { 14. One does not have to know History of Cyprus to be a cultured } \\
\text { person. }\end{array}$ & 270 & 33.75 & 218 & 27.25 & 136 & 17.00 & 108 & 13.50 & 68 & 8.50 & 2.36 \\
\hline $\begin{array}{l}\text { 16. I am not interested in History of Cyprus, except or the purposes of } \\
\text { doing homework. }\end{array}$ & 166 & 20.75 & 233 & 29.13 & 178 & 22.25 & 138 & 17.25 & 85 & 10.63 & 2.68 \\
\hline $\begin{array}{l}\text { 19. I do not like being asked to talk about "important issues" in the } \\
\text { History of Cyprus class. }\end{array}$ & 187 & 23.38 & 168 & 21.00 & 222 & 27.75 & 108 & 13.50 & 115 & 14.38 & 2.75 \\
\hline
\end{tabular}

Table 2. Definitive statistics on the scores obtained from Cyprus History Attitude Scale by students

\begin{tabular}{cccccc}
\hline & $\mathbf{N}$ & $\overline{\boldsymbol{x}}$ & $\mathbf{S}$ & Lower & Top \\
\hline Total score & 800 & 66.42 & 14.55 & 20 & 100 \\
\hline Item score & 800 & 3.32 & 0.73 & 1 & 5 \\
\hline
\end{tabular}

Table 3. Comparison of the Cyprus History Attitude Scale scores of students according to their personal characteristics

\begin{tabular}{ccccccc}
\hline Introductory characteristics & $\mathbf{n}$ & $\overline{\boldsymbol{x}}$ & $\mathbf{s}$ & $\mathbf{t} / \mathbf{F}$ & $\mathbf{p}$ & Tukey \\
\hline Gender & & & & & & \\
\hline Female & 400 & 67.59 & 14.97 & 2.28 & $0.02^{*}$ \\
\hline Male & 400 & 65.25 & 14.04 & & & \\
\hline Age group & & & & & & $1-2.1-3$ \\
\hline 12 and below & 68 & 74.97 & 12.55 & 10.46 & $0.00^{*}$ & $1-4.1-6$ \\
\hline 13 years of age & 137 & 65.96 & 14.55 & & $4-5.5-6$ \\
\hline 14 years of age & 133 & 66.30 & 15.39 & & \\
\hline 15 years of age & 194 & 63.51 & 13.96 & & \\
\hline 16 years of age & 172 & 69.45 & 13.85 & & & \\
\hline 17 and above & 96 & 61.60 & 13.64 & & & \\
\hline
\end{tabular}

${ }^{*} p<0.05,{ }^{* *}$ Not included in the analysis.

When the definitive statistics on the scores obtained by students from the Cyprus History Attitude Scale given in Table 2 are examined, it is seen that the average score obtained by the students from the entire scale is $66.42 \pm 14.55$ and the lowest and highest cores obtained from the scale were 20 and 100, respectively. It was determined that the item score mean obtained by students from the scale was $3.32 \pm 0.73$.

Table 3 presents the independent sample $t$ test and variance analysis results for the comparison of the Cyprus History Attitude Scale according to the personal characteristics of students. When Table 3 is examined, it can be seen that the female and male students included in the research received $67.59 \pm 14.97$ points and $65.25 \pm 14.04$ points from the Cyprus History Attitude Scale, respectively. It was determined that this difference between the scale scores of students according to their genders is statistically significant $(\mathrm{p}<0.05)$. Female students received statistically significantly higher scores from the scale than male students. 
Table 4. C Comparison of the Cyprus History Attitude Scale scores of students according to their education-related characteristics

\begin{tabular}{|c|c|c|c|c|c|c|}
\hline School characteristics & $\mathbf{n}$ & $\overline{\boldsymbol{x}}$ & $\mathbf{s}$ & $\mathbf{t} / \mathbf{F}$ & $\mathbf{p}$ & Tukey \\
\hline \multicolumn{7}{|l|}{ Grade } \\
\hline Secondary & 349 & 67.55 & 14.90 & 1.94 & $0.05^{*}$ & \\
\hline High school & 451 & 65.54 & 14.23 & & & \\
\hline \multicolumn{7}{|l|}{ Type of school } \\
\hline Public school & 704 & 66.49 & 14.55 & 0.41 & 0.68 & \\
\hline Private school & 96 & 65.84 & 14.64 & & & \\
\hline \multicolumn{7}{|l|}{ Report grade } \\
\hline 4 and below & 123 & 60.86 & 11.85 & 21.80 & $0.00^{*}$ & $1-3.1-4$ \\
\hline $5-6$ & 224 & 63.32 & 13.55 & & & $2-3.2-4$ \\
\hline $7-8$ & 237 & 67.11 & 14.85 & & & $3-4$ \\
\hline $9-10$ & 216 & 72.02 & 14.66 & & & \\
\hline
\end{tabular}

Students below 12 years of age who participated in the study received $74.97 \pm 12.55$ points on average, students at 13 years of age received $65.96 \pm 14.55$ points on average, students at 14 years of age received $66.30 \pm 15.39$ points on average, students at 15 years of age received $63.51 \pm 13.96$ points on average, students at 16 years of age received $69.45 \pm 13.85$ points on average, and students aged 17 and over received $61.60 \pm 13.64$ points on average. It was determined that there is a statistically significant difference between the scale scores of students depending on their age $(\mathrm{p}<0.05)$. The students who were 12 years or under received higher scores than students at $13,14,15$ and 17 years of age and above. Additionally, students at 16 years of age received higher scores compared to students who were 14 or 17 and over.

Table 4 gives the independent sample $t$ test and variance analysis results for the Cyprus History Attitude Scale comparison of students included in the study according to their education-related characteristics. Secondary school students included in the study received $67.55 \pm 14.90$ points from the Cyprus History Attitude Scale on average, whereas the high school students received $65.54 \pm 14.23$ points. It was determined that the difference between the scores obtained by students from Cyprus History Attitude Scale according to their grades was statistically significant and that the scores obtained by secondary school students from the scale were higher compared to high school students $(\mathrm{p}<0.05)$.

It was found that the difference between the scores obtained by students from the Cyprus History Attitude Scale according to the type of their school was not statistically significant $(\mathrm{p}>0.05)$. Although the scores obtained by the students at public schools was higher compared to students at private school, this difference was not statistically significant.

When the Cyprus History Attitude Scale scores of students are examined according to the report grades they had received the previous year, it can be seen that students with a grade of 4 or below for the previous year received $60.86 \pm 11.85$ points on average, students with a $5-6$ report grade for the previous year received $63.32 \pm 13.55$ points on average, students with a 7-8 report grade for the previous year received $67.11 \pm 14.85$ points on average, and students with a 9-10 report grade for the previous year received $72.02 \pm 14.66$ points on average. It was determined that the difference between the scale scores according to the report grades for the previous year was statistically significant $(p<0.05)$. Students with a report grade of 4 or below received lower scores than students with 7-8 and 910 report grades. The scale scores of students with report grade of 5-6 were lower than students with 7-8 and 9-10 scale scores. Additionally, the scale scores of students with report grades of 7-8 were found to be lower than students with report grades of 9-10.

Table 5 presents the variance analysis results for the comparison of the Cyprus History Attitude Scale scores of students included in the study based on their daily Internet usage, TV watching hours and newspaper reader habits. According to these results, students whose daily Internet usage totalled 1 hour received $70.44 \pm 14.57$ points from the Cyprus History Attitude Scale, students whose daily internet usage was 1-2 hours received $66.71 \pm 13.49$ points, students whose daily Internet usage was 2-3 hours received 67.89 \pm 15.03 points from the Cyprus History Attitude Scale, and students whose daily Internet usage was 3 hours and above received $63.03 \pm 14.25$ points. It was found that the difference between scale scores according to daily Internet usage was statistically significant $(p<0.05)$. Students with daily Internet usage of 3 hours and above received lower scores from the Cyprus History Attitude Scale compared to other students.

It was determined that the difference between the scale scores obtained by students from Cyprus History Attitude Scale according to the hours spent watching TV was not statistically significant ( $\mathrm{p}>0.05)$. Although the scale scores of students who watch television every day for 2 hours or more were lower compared to other students, this difference was not statistically significant. 
Table 5. Comparison of Cyprus History Attitude Scale scores of students according to their daily Internet usage, TV watching hours and newspaper reading habits

\begin{tabular}{|c|c|c|c|c|c|c|}
\hline & $\mathbf{n}$ & $\mathbf{x}$ & $\mathbf{s}$ & $\mathbf{F}$ & $\mathbf{p}$ & Tukey \\
\hline \multicolumn{7}{|c|}{ Daily Internet usage hours } \\
\hline 1 hour and below & 196 & 70.44 & 14.57 & 11.29 & $0.00^{*}$ & $1-4.2-4$ \\
\hline $1-2$ hours & 184 & 66.71 & 13.49 & & & $3-4$ \\
\hline $2-3$ hours & 119 & 67.89 & 15.03 & & & \\
\hline 3 hours and above & 301 & 63.03 & 14.25 & & & \\
\hline \multicolumn{7}{|l|}{ Daily TV watching hours } \\
\hline 1 hour and below & 328 & 66.74 & 14.28 & 1.62 & 0.20 & \\
\hline $1-2$ hours & 209 & 67.48 & 14.83 & & & \\
\hline 2 hours & 263 & 65.16 & 14.63 & & & \\
\hline \multicolumn{7}{|c|}{ Newspaper reading habits } \\
\hline Readers & 299 & 71.07 & 14.56 & 33.78 & $0.00 *$ & $1-2.1-3$ \\
\hline Non-readers & 301 & 61.68 & 13.85 & & & $2-3$ \\
\hline Occasional readers & 200 & 66.59 & 13.32 & & & \\
\hline
\end{tabular}

Table 6. Teacher opinions on the student-related problems of Cyprus History Teaching

\begin{tabular}{cc}
\hline Problem & $\mathbf{f}$ \\
\hline Problems caused by personal characteristics of students & 18 \\
\hline Students being insufficiently prepared & 4 \\
\hline Problems caused by learning abilities of students & 4 \\
\hline There are no student-related problems & 1 \\
\hline
\end{tabular}

Examination of the scores obtained by the students from Cyprus History Attitude Scale according to their newspaper reader habits revealed that students who read newspapers received $71.07 \pm 14.56$ points on average from the scale, students who did not read newspapers received $61.68 \pm 13.85$ points on average from the scale, and students who occasionally read newspapers received $71.07 \pm 14.56$ points on average from the scale. It was determined that the difference between the scale scores according to their newspaper reader habits was statistically significant $(\mathrm{p}<0.05)$. The scale scores of students who read newspapers were found to be higher compared to students who are non-readers and occasional-readers. Additionally, the scores obtained by students who occasionally read newspapers were higher compared to students who are non-readers.

\section{Qualitative Findings}

When Table 6 is examined, it can be seen that 27 different opinions were provided by teachers interviewed on the problems related to students in the Cyprus history class. Eighteen of these opinions are related to personal characteristics of the students, four are related to the level of preparedness of the students and four others are related to the learning abilities of students. One teacher argued that there were no student-related problems. Among the problems related to the personal characteristics of students, "low motivation", "lack of interest", "addiction to virtual world", "behaviours which disrupt class management", "problems of migrant children", "students being too comfortable", "were cited as problematic issues. Some of the teacher opinions are given below:

\footnotetext{
"Students are usually disinterested in all classes, which reduces their motivation" S8

"In regard to my school, almost $80 \%$ of students come from migrant families; thus, they do not have any preliminary knowledge about Cyprus and its history. This, in turn, prevents them from comprehending the subjects" S11
}

In relation to the problems related to the preparedness of students, it was found that student had problems with "negative effects created by previous learning", "inadequacy of previous learning" and "literacy issues". Some of the teacher opinions are given below:

"Previous learning of the students has an impact on the flow of the class. When history knowledge is not complete, this create problems in learning about the History of Cyprus in some cases." S2

"The fact that the education level of students is low, especially literacy problems in secondary schools, as well as some students finding Cyprus history class to be unnecessary are the problems that I face." S5 
Table 7. Teacher opinions on the most important problem in Cyprus History Teaching

\begin{tabular}{cc}
\hline The most important problem & $\mathbf{f}$ \\
\hline Course books with low quality & 11 \\
\hline Using history teaching as a political tool & 4 \\
\hline Insufficient time allocated for history classes & 4 \\
\hline Lack of environment and material that would enrich teaching of history class & 3 \\
\hline Problems caused by history teacher & 1 \\
\hline Problems related to students & 1 \\
\hline
\end{tabular}

In regard to problems related to learning abilities, it was found that problems were experienced in areas such as "desire for rote-learning" and "insufficient cognitive development". Some of the teacher opinions are given below:

\author{
"The basic problem is that students are educated through a rote-learning system" S10 \\ "Students come from elementary school with an incomplete understanding and it is too late to learn \\ something. We are having difficulty in doing what we desire. After 20 years, I think this job cannot be \\ done." S17
}

When Table 7 is examined, it can be seen that the problems considered least important by the teachers in Cyprus history are student-related problems. Other problems are course books, using history as a political tool, lack of time, lack of materials and teacher-related problems, in this order. The problems related to course book are discussed as follows: "insufficient information", "repetitive information", "too many visuals", "lack of course book". In terms of politics-related problems, "changing of history teaching policies caused by the frequent changes in government" and the "the lack of trust between Cypriot Turkish and Greek communities constantly affecting history teaching" were mentioned. Other problem headings appeared as "insufficient class hours", "lack of facilities/budget to deliver the class in a practical manner", "lack of sufficient documentaries", "some teachers emphasising their personal ideologies while discussing Cyprus History", and "lack of interest in students". Some of the teacher opinions are given below:

\author{
"Some teachers do not believe some of the covered topics are real." S9 \\ "The contents of course books, which are full of repetitive and monotonous information, are insufficient \\ and void. Some of the information is conflicting." S13 \\ "There is no budget for research and practical field studies" S12 \\ "The most important problem is that there are very few documentaries on Cyprus history (which also \\ cover the topics)". S20 \\ "Class hours are limited" S4 \\ "The most important problem is the lack of trust between Turkish Cypriot and Greek Cypriot \\ communities." S19
}

\title{
CONCLUSION AND DISCUSSION
}

In this study, which is based on the attitudes of students in Cyprus history teaching on the basis of postmodern education, when the descriptive statistics of the scale are examined, it can be observed that students particularly have reduced interest in such topics as "using Cyprus History in solving daily problems" and "reaching and reading documentaries, diaries, magazines, newspapers etc. sources on Cyprus History". However, Aytekin (2009) argued that relating history education with daily incidents is very important in terms of obtaining a global perspective and for broadening life experience. Problems experienced in this area indicate that Cyprus history classes are not given at the desired quality. On the other hand, among the positive items, the most preferred, meaning the item with the highest attitude of students, was "I am trying to do my best in the History of Cyprus class". This shows that students have self-esteem and self-confidence. Self-esteem is a very critical topic in education (Morgül et al., 2016).

An examination of the scale items in terms of the negative items shows that students do not read any source books other than the course book. This is problematic and it could be due to several reasons; for example, the failure of teachers to direct students, lack of knowledge of teachers on other sources, failure to allocate time for other 
activities due to high workload, or students not having access to other sources due to socio-economic reasons etc. In that case, the quality of Cyprus History course books becomes even more important, as they are the only sources used for the class. When the overall attitudes of students are evaluated based on the scale results, it can be seen that their attitudes are at a medium level. This result is promising, as the attitude is not below average level; however, in order for education to be successful, all learning must be conducted in an effective manner (Şimşek, 2010). In this context, improving the Cyprus history attitude level of students from medium to good or very good levels is critical.

An examination of the Cyprus history attitude scores of students based on their personal characteristics shows that there is a significant difference in gender and age variables. The attitude level of female students is higher than male students; furthermore, the attitude levels of students who had just started secondary school was found to be higher and it was evident that, as the years passed, this attitude level was not maintained but decreased (İskender, 2007; Akbaba et al., 2014; Şimşek, 2010). It is particularly meaningful that as the students become older, their attitude levels decrease. As students have more history knowledge and spend more time focusing on history, it is expected that their attitude level would increase; however, the opposite result was observed as their attitudes decreased. It is necessary to determine the reasons for this and to conduct more in-depth qualitative research into this problem.

An examination of the Cyprus history attitude scores of students based on their education-related characteristics showed that there is no significant difference between public schools and private schools. However, considering the equipment, tools and materials that private schools can offer, it was expected that the difference would be observed in favour of private schools. This result shows that teachers do not deliver student-centred education adequately and private schools are not an alternative for public schools. Another important result is that academic success and attitude towards class are moving in the same direction. In the literature, there are studies that demonstrate that academic success and attitude levels develop together in history education (Ulusoy, 2009; Ulusoy\& Gülüm, 2009; Gül \& Yılmazer, 2016; Turan, 2015; Kamer \& Şimşek, 2016; Akbaba et al., 2014).

When the Cyprus history attitude scores of students are related to technology-focused subjects, it can be seen that the attitude level of the students who used the Internet less was higher; however, no significant difference was detected in terms of hours spent watching television. In modern society, television is a less significant factor in people's lives compared to the past and the Internet has overtaken television as the preferred medium (Yaman \& Erdoğan, 2007; Çelen, 2011). Finally, when the Cyprus history attitude scores and newspaper reading habits are examined, the attitude level of newspaper readers was revealed to be higher compared to non-readers. Naturally, it is obvious that people who love reading and read habitually will like the history class more. The literature provides examples of similar conclusions (Yıldırım \& Şimşek 2017, Turan 2015, Elban 2015, Şimşek 2010, Şam 2007) and this research confirms this reality.

The study also examines the opinions of history teachers based on Cyprus history teaching on the basis of postmodern education in regard to Cyprus history classes and shows that teachers assign importance to Cyprus history teaching. It has been found that teachers are focused on developing and improving history teaching by reducing the reliance on rote learning methods. Studies conducted by Mutluer (2015) and Şam (2007) support this finding.

According to the referred teacher opinions, the student-related problems encountered in Cyprus history teaching are predominantly related to the personal characteristics of the students. One of the most important reasons for this is that students coming from Turkey and students with Cypriot origins are taking Cyprus history lectures in mixed classrooms. The Cyprus history class does not attract the attention of students from Turkey. This is essentially due to the fact that history is a matter of curiosity. In particular, the curiosity about one's own ethnic roots increases the interest in this history classes (Öksüz et al., 2016; Türkan, 2016).

\section{RECOMMENDATIONS}

The fact that "I am trying to do my best in the History of Cyprus class" was given high value in this research demonstrates that the level of knowledge and skill of students can be increased easily if teachers deliver high quality education.

An examination of the literature indicates that there are serious problems related to the history course books that are used in classrooms today (Bal, 2011; Gül \&Yılmazer, 2016; Akbaba et al., 2016; Latif, 2010; Papadakis, 2008). This problem should be addressed immediately. Additionally, as emphasised in postmodern education, teaching must not only be based on course books; the search for high quality audio-visual and linguistic sources must continue (Bal, 2011; Gül \&Yılmazer, 2016; Korkmaz \& Güneyli, 2017; Yang, Yu, Gong \& Chen, 2017).

As the study indicated that academic success and attitude towards class are moving in the same direction, it is essential that the attitude level of students and their academic success should be addressed and developed together.

The teachers whose opinions were sought in the study displayed their positive and negative opinions on the execution of the Cyprus history class, which indicates that teachers are knowledgeable in this area attempt to find 
solutions to the problems. This result is promising in terms of solving the problems encountered in teaching of Cyprus history.

The teachers whose opinions were sought expressed that the most important problem experienced in Cyprus history classes was related to the Cyprus history course books. In particular, the fact that course books are of low quality, are insufficient or full of unnecessary excessive knowledge, and are written in accordance with governmental policies are the problems that teachers experience. This view is supported by Yıldırım and Şimşek (2017), Turan (2015), Vural and Özuyanık (2008), Papadakis (2008) and Latif (2010). It can be said that the attitudes of students in regard to Cyprus history course books correspond to the teacher opinions. For this reason, regulation is needed in terms of the Cyprus history course books, which must be designed according to the new approaches in education.

Teachers whose opinions were sought mentioned that they experienced problems in terms of insufficient class hours, the classroom environment and a lack of materials, which consequently had a negative impact on Cyprus history teaching.

Previous studies support the view that a lack of tools-equipment and an unfavourable classroom environment in education and teaching influence student learning (Gül \& Y1lmazer, 2016; Öztürk, 2009; Akbaba, 2003, Demircioğlu, 2007; Safran \& Ata, 1998; Şimşek, 2003; Latif, 2010). The relevant ministry must give support to organizing teaching environments and removing deficiencies in particular and efforts must be made to rectify the deficiencies.

\section{REFERENCES}

Akbaba, B. (2005). İnkılap Tarihi Öğretiminde Fotoğraf Kullanımı. Türk Eğitim Bilimleri Dergisi, 3(1), 65-78.

Akbaba, B., Demirtaş, B., Birbudak, T. S., \& Kılcan, B. (2014). Tarih Öğretmeni Adaylarının Atatürk İlkeleri Ve İnkılâp Tarihi Öğretimine Yönelik Görüşleri. Zeitschrift Für Die Welt Der Türken/Journal Of World Of Turks, 6(2), 207-226.

Aktekin, S. (2009). Türkiye'de Tarih Eğitimi. Çok Kültürlü Bir Avrupa İçin Tarih Ve Sosyal Bilgiler Eğitimi, 27-44.

Aydın, H. (2006). Eğitimde Modern ve Postmodern Modeller. Bilim ve Gelecek Dergisi, 33, 60-69.

Bal, M. S. (2011). Türkiyede Tarih Öğretiminin Sorunları Ve Çözüm Yolları Konusunda Öğretmen Adayı Ve Öğretmen Görüşlerinin Karşılaştırılması/A Comparıson Of Vıews Of In-Servıce And Pre-Servıce Teachers On Problems Of History Teaching And Solutions For These Problems. Mustafa Kemal Üniversitesi Sosyal Bilimler Enstitüsü Dergisi, 8(15).

Bal, M. S. (2014). Türkiyede Tarih Öğretiminin Sorunları Ve Çözüm Yolları Konusunda Öğretmen Adayı Ve Öğretmen Görüşlerinin Karşılaştırılması, 371-387.

Carda, E. (2013). The Quest İn Postmodern Literature: An Analysis Of The Quest İn Thomas Pynchon's The Crying Of Lot 49 And Paul Auster's City Of Glass. Universty Of Wien, Magistra Der Philosophie.

Cunce, S. (2001). Sözlü Tarih ve Yerel Tarihçi (çev: B. Bülent Can, Alper Yalçınkaya). İstanbul: Tarih Vakfı Yurt Yayınları.

Çelen, F. K., Çelik, A., \& Seferoğlu, S. S. (2011). Türk Eğitim Sistemi Ve PISA Sonuçları. Akademik Bilişim, 2(4), 1-9.

Demircioğlu, İ. H. (2007). Tarih öğretiminde filmlerin yeri ve önemi. Bilig, Yaz/42, 77-93.

Doll, W. E. Jr. (1993). A Post-Modern Perspective on Curriculum. New York: Teachers College Press, xvi + 232. ISBN 0-807-73217-6.

Doltaş, D. (2003). Postmodernizm ve Eleştirisi, Tartışmalar, Uygulamalar. Ankara: İnkılap Yayınları.

Elban, M. (2015). Ortaöğretim Öğrencilerinin Tarih Dersine İlişkin Tutumları: Ankara İli Kazan İlçesi Örneği. Turkish Journal Of Educational Studies, 2(2).

Fetter, J. P (2011). Alternative Styles in String Music Education: Identity Development and Curriculum Design in the Postmodern Era (Doctoral Thesis). Department of Music Education Eastman School of Music University of Rochester Rochester, New York

Gül, K. O., \& Yılmazer, A. (2016) Ortaokul 8. Sınıf Öğrencilerinin T.C. İnkılâp Tarihi Ve Atatürkçülük Dersine Karşı Tutumları İle Akademik Başarıları Arasındaki İlişkinin Farklı Değişkenler Açısından İncelenmesi, International Journal Of Social Science, 51, 517-537.

Harvey, D. (2003). Postmodernliğin Durumu (çev: Sungur Savran). İstanbul: Metis Yayınları.

Hollinger, R. (2005). Postmodernizm ve Sosyal bilimler, Tematik Bir Yaklaşım (çev.Ahmet Cevizci). İstanbul: Parardigma Yayınlar1. 
Hughson, J. (2013). The Postmodernist Always Rings Twice: Reflections on the "New" Cultural Turn in Sports History. The International Journal of the History of Sport, 30(1), 35-45. doi:10.1080/09523367.2012.740665

İskender, P. (2007). Öğretmen Adaylarının Tarih Dersine İlişkin Tutumları. Kastamonu Ĕ̆itim Dergisi, 15(2), 631-638. Jencks, C.(2010). What is Postmodernism? New Jersey: John Wiley \& Sons Ltd.

Kamer, S. T., \& Şimşek, A. S. (2016). Türk Eğitim Tarihi Dersine Yönelik Öğretmen Adaylarının Tutumlarının Ölçülmesi. Journal Of Kirsehir Education Faculty, 17(2).

Korkmaz, S., \& Güneyli, A. (2017). Impact of Technology-Assisted Context-Based Teaching on the Listening Skills of Teacher Candidates. Eurasia Journal of Mathematics, Science \& Technology Education, 13(8), 4669-4677.

Latif, D. (2010). Dilemmas of moving from the divided past to envisaged united future: Rewriting the History Books in the North Cyprus. Special Issue Int'l J. Educ. L. E Pol'y, 35.

Lixin, L. (2004). Letter to my sister about Doll's 4R's. Transnational Curriculum Inquiry, 1(1) http:/ / nitinat.library.ubc.ca/ojs/index.php/tci.

Lyotard, J. F. (2000). Postmodern Durum (çev: Ahmet Çiğdem). Ankara: Vadi Yayınları.

McCrum, M. E. (2010). Teaching History in Postmodern Times: History Teachers' Thinking about the Nature and Purposes of Their Subject. Professional Doctorate in Education University of Sussex.

Morgül, İ., Seçken, N., \& Yücel, A. S. (2016). Kimya Öğretmen Adaylarının Öz-Yeterlik İnançlarının Bazı Değişkenler Açısından İncelenmesi. Balıkesir Üniversitesi Fen Bilimleri Enstitüsü Dergisi, 6(1), 62-72.

Mutluer, C. (2015). Tarih Derslerinin Tolerans Eğitimindeki Yeri: Tarih Öğretmenlerinin Görüşleri. Electronic Turkish Studies, 10(11).

Nicholls, J. (2006). The Possibilities for Comparing a Syllabus Topic in School History Across Cultures (Degree of D.Phil). Educational studies, Universty of Oxford.

Öksüz, Y., Demir, E. G., \& Adem, İ. C. İ. (2016). Öğretmenlerin Ve Öğretmen Adaylarının “Çokkültürlü Eğitim” Kavramına İlişkin Metaforlarının İncelenmesi. Elektronik Sosyal Bilimler Dergisi, 15(59).

Özer, E. (2012). Sosyal Bilgiler Dersinde Yerel Ve Sözlü Tarih Etkinliklerinin Programlanması (Unpublished Masters Thesis). Konya Üniversitesi, Eğitim Bilimleri Enstitüsü.

Öztürk, İ. H. (2009). Yeni Ortaöğretim Tarih Programları Üzerine Eleştirel Bir İnceleme. The First International Congress of Educational Research, 1-3 May 2009, Çanakkale.

Papadakis, Y. (2008). Narrative, Memory and History Education in Divided Cyprus: A Comparison of Schoolbooks on the" History of Cyprus". History \& Memory, 20(2), 128-148.

Safran, M. (1993). Değişik Öğrenim Basamaklarında Tarih Dersine İlişkin Tutumlar Üzerine Bir Araştırma. Ĕ̆gitim Dergisi, 2, Ankara.

Safran, M., \& Ata, B. (1998). Okul dişı tarih öğretimi. GÜ Gazi Eğitim Fakültesi Dergisi, 18(1), 87-94.

Sarup, M. (2004). Post-yapısalcılık ve Postmodernizm (çev: Abdülbaki Güçlü) (2.Baskı). Ankara: Bilim ve Sanat Yayınlar1.

Şam, E. A. (2007). Amasya Eğitim Fakültesinde Farklı Bölümlerde Okuyan Öğretmen Adaylarının Tarih Dersine İlişkin Tutumları. Gazi Üniversitesi Gazi Eğitim Fakültesi Dergisi, 27(3).

Şimşek, A. (2003). Tarih öğretiminde görsel materyal kullanımı. GÜ Kırşehir Eğitim Fakültesi Dergisi, 4(1), 143-157.

Şimşek, A. (2010). Sınıf Ve Sosyal Bilgiler Öğretmen Adaylarının Tarih Öğretimine İlişkin Tutumları. International Online Journal Of Educational Sciences, 2(1).

Thompson, P. (1999). Geçmişin Sesi (çev: Şehnaz Layıkel). İstanbul: Tarih Vakfı Yurt Yayınları.

Tosh, J. (2005). Tarihin Peşinde (çev: Özden Arıkan) (2. Baskı). İstanbul: Tarih Vakfı Yayınları.

Turan, R. (2015). Tarih Öğretmenlerinin Lise Tarih Derslerinin Genel Amaçlarının Öğrencilere Kazandırılma Düzeylerine İlişkin Görüşleri (Ankara İli Örneği). Turkish Journal Of Educational Studies, 2(3).

Turkan, A., Aydın, H., \& Üner, S. S. (2016). Öğretmen Adaylarının Çokkültürlü Eğitim Tutumları İle Epistemolojik İnançları Arasındaki İlişkinin İncelenmesi. İlköğretim Online, 15(1).

Ulusoy, K., \& Gülüm, K. (2009). Sosyal Bilgiler Öğretmenliği Öğrencilerinin Tarih Ve Coğrafya Derslerine Yönelik Tutumları (Adıyaman Örneği). Dumlupınar Üniversitesi Sosyal Bilimler Dergisi, 25.

Vural, Y., \& Özuyanık, E. (2008). Redefining İdentity İn The Turkish-Cypriot School History Textbooks: A Step Towards A United Federal Cyprus. South European Society And Politics, 13(2), 133-154.

Yaman, H., \& Erdoğan, Y. (2007). İnternet Kullanımının Türkçeye Etkileri: Nitel Bir Araştırma. Journal Of Language And Linguistic Studies, 3(2). 
Yang, J., Yu, H., Gong, C., \& Chen, N. S. (2017). Students' Perceptions and Behaviour in Technology-Rich Classroom and Multi-Media Classroom. Eurasia Journal of Mathematics, Science E Technology Education, 13(3).

Yıldırım, T., \& Şimşek, A. (2017). Erken Cumhuriyet Döneminde “Biz” İn İnşası: Tarih Ders Kitapları Üzerine Bir Değerlendirme. Gazi Üniversitesi Gazi Eğitim Fakültesi Dergisi, 37(1).

http://www.ejmste.com 